\title{
SUPPORTING THE ABSORBENT NATIONAL RURAL DEVELOPMENT PLANNING BY SCENARIOS
}

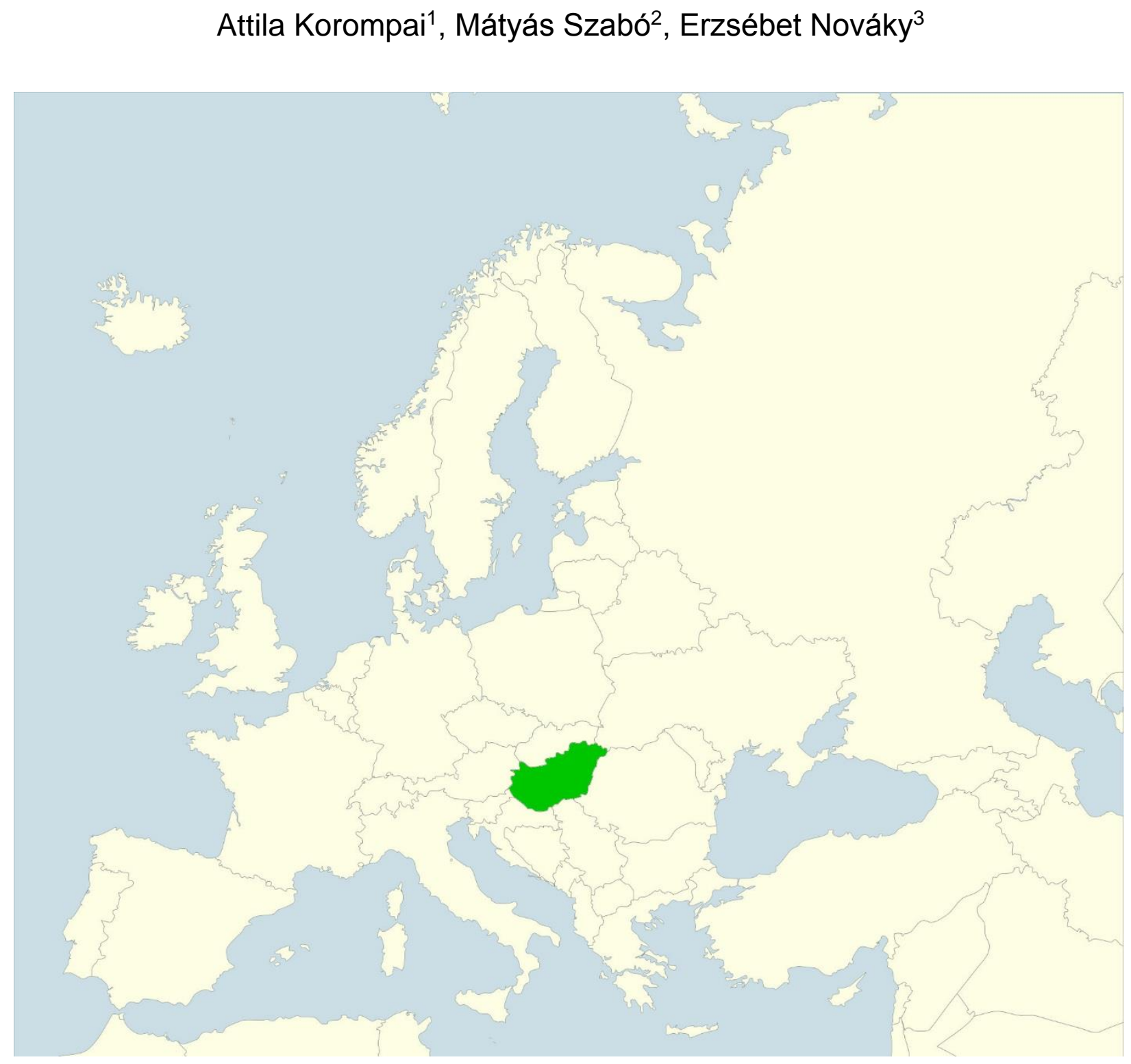

\footnotetext{
${ }^{1}$ Assoc Prof. Attila Korompai, PhD., Centre of Economic Geography and Futures Research, Faculty of Social Sciences and International Relations, Corvinus University of Budapest, Fövám tér 8, 1093 Budapest, Hungary; e-mail: Attila.korompai@uni-corvinus.hu

2 Ass. Prof. Mátyás Szabó, PhD., Department of European Studies, Faculty of Social Sciences, Eötvös Loránd University, Egyetem tér 1-3, 1053 Budapest, Hungary, e-mail: szabotmatyas@caesar.elte.hu

${ }^{3}$ Prof. Erzsébet Nováky, DSc., Centre of Economic Geography and Futures Research, Faculty of Social Sciences and International Relations, Corvinus University Budapest, Fövám tér 8, 1093 Budapest, Hungary; e-mail: erzsebet.novaky@uni-corvinus.hu
} 


\begin{abstract}
The practice of Hungarian rural development planning shows the lack of future orientation. The time horizon of planning is short-term, the strategic way of thinking beyond 7-10 years long period is missing or it has great deficiencies. It is not even considering the long-term opportunities. Therefore, the short term plans are not derived from established perspectives, they do not have sufficient grounds. This paper briefly summarises the achievements of a research activity to make an attempt to prove that despite the limitations in understanding and unfolding the future, it is possible to provide useful information for the planning of rural development in 20 30 years or even on several more years. This is based on pre-scenarios, highlighting the high efficiency and unexpected weak signals of the driving forces.
\end{abstract}

Keywords: Spatial planning, rural development, futures studies, scenarios, weak signals

\begin{abstract}
Absztrakt: A magyarországi vidékfejlesztési tapasztalat, hogy a hazai térségfejlesztés gyakorlatában nem jelenik meg a hosszú távú kitekintés, a szakma 7-10 éves távlaton túlra nem tervez és nem is méri fel a lehetőségeket. A hosszú távból eredeztethető rövid távú tervek így nem rendelkeznek megfelelő alappal. A cikk röviden bemutatja a kutatást, amely megkisérli, hogy bizonyítsa: a jövő megismerésének nyilvánvaló korlátai ellenére lehet a vidékfejlesztési tervezés számára hasznos információkat nyújtani 20-30, esetleg még több évre elöre; forgatókönyvi bázison kiemelve a nagy hatásfokú, de váratlan gyengejeleket a hajtóerök közül.
\end{abstract}

Kulcsszavak: Területi tervezés, vidékfejlesztés, jövőkutatás, forgatókönyvek, gyenge jelek

\title{
1. Introduction
}

Concerning the Hungarian planning practice Attila Korompai (Korompai 2006, 216-219) pointed out these "inconsistencies":

- Due to the excessive desire for the complex exploration of the present, the future drivers get lost, thus the situation report is not future-oriented. In fact, it is methodologically incorrect, since the statistical data always refer to an earlier period, never to the actual present, so our knowledge about the present is already limited.

- If the future opportunities are finally outlined, these are done as development projects, instead of „as outlines of future trends and conditions providing frameworks for future projects". So they do not formulate external factors, but the Authors own desires.

The National Sustainable Development Council (hereinafter NSDC) state that "in politics: the present is always more important than the future", justified by the shortness of political cycles and the demographic features. According to the NSDC's "Future Finder" report, politics is growthoriented (it measures its short-term effectiveness), therefore sustainable, long-term thinking is not expected. The report also condemns the fact that "... there is no common framework for each of the plans and programs, as their actions are based on opportunities rather than on real social needs. The involvement of environment is necessary into a comprehensive framework document that follows a social vision. Hungarian society is divided into the sea of external influences without a single, common vision, and as a result, it is incapable of gathering and enforcing its internal possibilities" (NSDC 2010, 22).

According to the current Hungarian rural development practice, the documents for the future (concepts, strategies) are based on situation assessments, without the examination, pre-esteem of different versions concerning the expected future (see the vision of the National Rural Strategy [page 54-55.]). The processes beginning in the past, continuing in the present and affecting the future are not known and revealed, the factors and key settings greatly influencing the future are not investigated. The rural policy is thinking in short-term perspectives - in political cycles in general - instead of historical perspectives. The probable, desirable and possible evolution of 
the future is not influencing the endeavours. Today, the rural plans existing and under preparation in our country include a future image, but it is characterised rather as a dream or a vision. Our plans are not featured as future-oriented, but as resource-centred. Not the features of a given region or the inhabitants' expectations determine the plans, actions, but the available financial resources, namely the tenders, the actual availabilities. Our resources are concentrated on tenders and not for the needs, because EU rural funding may not be available for these needs and their implementation would require harder and longer work.

The documents related to EU funding (New Hungary Rural Development Strategic Plan, New Hungary Rural Development Program) by their characteristics are medium term budgets adjusted to the 7-year EU financial cycles. The vision described in them is based on a narrow sectoral logic. National strategies are either unrelated or there is a weak link. It can be concluded, that the lack of future awareness is a significant problem in the domestic, practical rural development planning (Allmendinger and Haughton 2010, 803-818). The vast majority of plans on one hand, do not have a well-founded complex vision (Schwartz, 1996), or they just contain the desired future without surveying the limits of the opportunities. One the other hand the foundation of the plans by scenarios (Schoemaker 1995) is completely missing.

Future orientation has many benefits for design. Of course, the "moving target" character makes it impossible to forecast the future as the future changes dynamically, so it is not possible to give a "description" about it (Bóna in: Gábor eds. 1976, 67), and it is also a barrier to know that "Social and natural processes associated with strategies are linked to large, complex systems. Understanding their structure and functioning is greatly complicated by the fact that both their structure and their behaviour are not embraceable and untraceable for their entirety. In relation with them, the irregular behaviour is not a rare phenomenon at all. Small changes that appear to be insignificant may create radically new situations, circumstances, processes or events that may be of great significance but may either have unimportant consequences "(Korompai 1995, p. 16). Faragó's often highlighted message that "from the 'is' does not come the 'has to be"' (Faragó $2003,2005)$ there is a future-oriented "translation" that can be utilised when interlinked with design. The needs of the present do not come from the future need because there are other characteristics of a different state, so meeting the "new" needs also needs to be "different" in the "new" way. Enyedi also considered in one of his last writings (Enyedi 2010, 400-401) that basic research in spatial development (including rural development, even in a quoted article) should not solve the practical problems of the present but it has to outline new socio-economic processes. The goals that will evolve in the future will make problems for the future. At present, in this context, our task is to solve our present problems in a way that will decrease unfavourable consequences in the future on one hand, but on the other hand to initiate and support the germs of favourable conditions and opportunities. Both are possible only by intensive futures studies. In recent years, futures research has also shifted from prognostication to community-based and participative planning-oriented scenarios to unfold possible processes, movements or events. However, forecasts usually do not work when we really need them, particularly when there are big breaks in trends (Kristóf 2002, 4). If we accept the uncertainty, we also accept that the solution is not a further refinement of the mathematical-statistical methods but understanding and managing uncertainty by means of the scenario method. Information about the future is also needed for reducing uncertainty about the future both in terms of the interests to be applied to the strategy and the environment (Korompai 1995, 23).

The recognition of these critical points and a change of attitude is required for domestic planners to achieve, that the plans to be elaborated become complex and future-oriented, not just in theory but in reality too. The objective of this research is therefore to question and to prove that with the use of instruments of futures research, a well-grounded system can be produced, which takes into account the future possibilities and expectations and facilitates planning. The task of the research is the systematisation of knowledge established by futures studies from the aspect of its utilisation for an improved rural planning. The key points to this new approach to rural planning are summarised in the hypotheses. 


\section{Hypotheses}

When formulating the hypotheses, the authors tried to use systematic "planners' hypotheses", if possible, in the form of "more" type propositions. This aspect means that a given hypothesis reacts to the themes of rural development planning, while it also supports the use of futureoriented planning methodology with methodological assumptions (Roney 2010, 71-100). All assumptions concentrate on grounding two fields. The first area seeks to manage the key factors and to justify their highlighted importance in planning. It is displayed in the $\mathrm{H} 1$ group. The other equally important field focuses on functional changes in rural areas and their consequences. This is the group $\mathrm{H} 2$.

$\mathrm{H} 1$ : The more key factors we can define, the more justified scenario can be developed.

H1.1: The more powerful signals, trends, critical uncertainties and weak signals (Veigl 2009) can be identified, the more divergent scenarios can be prepared for macro-planning.

H1.2: The more complex system is examined, methodologically the more efficient is to take for scenario axis a dependent factor which is in the intersection of interactions, and because through the interactions it can modify „back” the other key factors i.e. it may create repercussions.

H1.3: The more complete is the assessment of interactions between key factors, the more complex scenarios can be formed.

H1.4: The more, different quality scenarios are formed, the more comprehensive will the framework be for rural development.

$\mathrm{H} 2$ : Initially, the main aim of the domestic rural areas was to meet the nutritional needs, therefore the main target areas of planning were agricultural factors, whereas in the future, the main focus will be placed on social factors.

$\mathrm{H} 2.1$ : The more shifts in the main profile of rural areas from agricultural functions to social functions, the more becomes the main task of rural development planning to search for replacing old profiles with new ones.

H2.2: The less agriculture becomes the main function of rural areas, the more the fight against poverty, the environmental protection (where the intervention logic is made by the recognition that the environment has high impact on both the economic and social sectors) and the technological innovation will be the key development priority of rural development strategies, as these disciplines could dominate the new profile of rural areas.

H2.3: The key development factors of rural areas should be selected from the fields of the fight against poverty, from environmental management (e.g. climate adaptation) and technological innovation, because the present external and internal circumstances of rural areas in these elements offer relevant development and manoeuvring opportunities.

H2.4: With greater involvement and satisfaction of urban social interests in rural areas (sustainable land use, renewable energy producing etc.), the urban-rural relationship transforms.

H2.5: With the greater accomplishment of new profiles in rural areas - based on social, environmental and innovation factors, the differences in the quality of life between the countryside and the urban areas will be reduced.

The proof of $\mathrm{H} 1$ hypotheses verify that the final scenarios cover a wide range of future versions, emphasising weak signals due to their critical uncertainties guarantee the creation of real alternatives, a kind of removal from the "common logical framework". With the withdrawal "from the box" progressive, advanced scenarios showing new ways can be formed, therefore, for various rural development areas new „opportunities” can be unfolded. If the statements of H2, i.e. the group of hypotheses referring to content elements of rural development planning, were not verified, or most of the statements were not proven, it would mean that the agricultural function 
of rural areas continues to be dominant. Therefore, rural development either has to increase its efforts to promote the the coordination with the emerging new needs beside the agricultural development, or relying on the agricultural development, it should try to start rural social, environmental, innovative processes, which may spill over the agricultural sector.

Both unfolding the future and generating motivation to attain the objectives included into the development plans based on the unfolded future need active participation both in the elaboration of alternatives and in the planning decisions. This is realised in the frame of absorbent development planning. This research intends to be a contribution to the foundation of this type of planning.

\section{Methodological overview}

The analysis and the development of scenarios are based on methods of collective expert opinions. The authors chose the SEER ${ }^{4}$ method (Nováky ed. 2006) and the related dual-line scenario creating (Kristof, 2002). These are suggested to planning problems with numerous, not fully aggreative, not quantifiable, but closely related key factors. Their systems approach is advantageous to achieve the foundation of a more comprehensive rural planning. Undoubtedly, subjectivity may be raised in connection with them, but the involvement of experts with various experiences may decrease this type of bias.

The research has two phases:

- at firstly the identification and evaluation of driving forces and key factors are aimed,

- lastly, the development and re-evaluation of scenarios are targeted.

In both phases, questionnaires and interviews are applied to elaborate the scenarios based on collective knowledge. The combination of questionnaires and interviews is appropriate because of the numerous scopes, and the results can be further developed on the basis of opportunities to get feedbacks and opinion changes. It fits to the profile of the research looking primarily for qualitative characteristics, not for quantitative data.

The surveys were made with the participation of experts, students and researchers working in the field of rural development. The target groups of the poll were determined in such a way that a relatively small "manageable" with doctoral resources to sample size could represent the unacademic and academic society interested in national rural development geographically, scientifically and in age structure. Using the thematic representation method, the selection was focused on those individuals who may become members of the "Rural Projects Class" (Kovach 2012) in the future. Therefore, they may substantially affect the development of rural areas and with participation in the research, they may consider future issues and might be encouraged by the activity. The sample in the case of universities, doctoral schools was random, while all the LEADER LAGs were requested. The sample in this context is representative from territorial point of view, due to involving all LEADER groups. This made it possible to depict the geographically diverse aspects.

The questionnaire was sent to 90 LEADER Local Action Groups (LAG), 30 universities and 10 graduate schools who have rural development studies. The answers came back from the representatives of the LAGs or the individual students through a website in an anonymous way. The willingness to answer was $29 \%$, the period when this research took place was between 1 February 2014 and 7 April, and was followed by the processing. The paper version of the questionnaire contained relevant driving forces. It was focused on three questions: give values to the factors, estimate their probability and their efficiency and propose the missing factors.

Important methodological issue is the identification of the time horizon for scenario-development. As the cycles connected to rural processes are largely determined by natural characteristics (the slow change of the flora and fauna, landscape etc.), rural development planning should be concerned in long-term cycles as „futures research".

\footnotetext{
${ }^{4}$ SEER $=$ System for Event Evaluation and Review
} 
In this research, the time horizon of scenarios to be elaborated was extended until 2050, all the more so since a number of global models and scenarios were adjusted especially to the turning point of climate change, which also identify this "mysteriously distant", easy to communicate date (see Jorgen Randers: A Global Forecast The Next Forty Years 2052; or from Meadows, D. H. Meadows, D. L. Randers, J. Behrens, W. W. (1972): Limits to growth; and more: WBCSD Global Scenarios 2000-2050; OECD Energy 2050; Global Normative Scenario - 2050 etc.). An additional reason to set this date is that this 35-year time span is not considered by experts too long for the exploration of the future with scenario building. In this time span, the number of bifurcations is not that high that it would be unmanageable. The selection of this time horizon is confirmed by technological foresight experiences on estimating the perspectives of technological level, and also by our knowledge on research directions, and the likely "date" of outcomes (Kiss in: Nováky edit. 2008, 75). A prominent role is given to the innovation in the scenarios considering the technological researches as weak signals.

The major structural trends are taken into account as external and given factors. This, about onethird century does not mean any limit for the perspectives of planning. Many strategies are made to achieve the conditions projected for the mid-century, particularly in the EU, which has an advanced planning activity (see the documents "The EU transport timetable for 2050: the interconnected networks are the future" or "The Roadmap up to 2050 for a competitive economy with low-carbon emission"). Planning up to 2050 is not impossible, but it was missing from the national rural development planning (and from the Hungarian regional development). The intention of this study is to demonstrate the lack of it not carrying out the greatest work, and its necessity too.

\subsection{Identification of key factors and driving forces}

A short summary based on national strategies and documents, as well as EU level studies ${ }^{5}$ presents the latest situation of the (in this case Hungarian) countryside in order to explore the key influencing factors and drivers of rural development. To ensure the complexity of the analysis for scenario development, the investigation combines STEEP ${ }^{6}$ and SWOT ${ }^{7}$ analyses for an overview of the situation, presenting SWOT elements in the categories of STEEP. The adaptation of both methods contributes towards the completion of the mapping of internal and external environment; it helps to detect the key factors, and to identify their interactions with each other. Unlike the SWOT analysis, which is widespread in the Hungarian rural development planning, the involvement of STEEP into the research is a methodological innovation, because its usage is much less familiar. Although in other planning fields (business planning, regional planning, etc.), it proved to be an effective and recognised method to explore factors, and to increase the potential in complex problem solving. Another reason of the above-mentioned deficient planning practices can be the insufficiently assessed present situation that is caused by the sole and exclusive use of the SWOT. It does not take into account some essential elements owing to which the national rural development planning is visibly ineffective. Even if one does not learn from the negative experiences, one has to try to step out of the usual circles of thought and tools

In the SWOT-analysis only the factors identified in the above-mentioned documents are appearing beside the elements reflecting the authors' professional opinion. Elements not appearing in the SWOT-analysis but factors needed for the STEEP analysis - like political factors - are taken from referred sources.

The advantage of SWOT prepared on the basis of several documents is that the collective knowledge already appears in the early stages of the research, since the referred materials were prepared following a wide-range public debate or with active professional involvement (for example in the NAKVI's project at the end of 2012, more than 10 thematic, national working groups had been working on the SWOT analysis).

\footnotetext{
${ }^{5}$ e.g. „European Rural Futures” project and the 2014-2020 plannig project of the National Agricultural Advisory, Training and Rural Development Institute [hereinafter NAKVI]

${ }^{6}$ STEEP = Social, Technological, Economical, Environmental and Political

7 SWOT = Strengths, Weaknesses, Opportunities, Threats
} 
Based on the situation analysis, the full range of influencing factors and drivers cannot be identified but a list of potential agents may be created. However, from the "list" the "biggest trouble," the "most important advantage, opportunity", the most influencing factors, etc. cannot be highlighted. Due to the complexity of the countryside, each one more or less affects the countryside as a driving force. They vary in space and time, they exert their effects sometimes only at local level, sometimes only marginally. For the purpose of macro-level scenario making in line with the aim of this research - we need only the factors relevant on macro level.

The first step of scenario-making is the exploration of driving forces. This is based on the following stages:

1. From the driving forces identified during the STEEP and SWOT analyses, these are sorted, which are driving forces from the aspect of the 2050 perspective.

2. The drivers for the future are examined in terms of their impact and their uncertainty.

From contemporary driving forces, which are relevant at the national level, not all would be a driving force in 2050 (49 element). By that time, for example, several factors will get over the peak of their influencing power, and they become either a declining factor (so their trenddeflecting strength would pass), or they would become obsolete due to the development, or simply a qualitative leap may happen by that time. Another group of drivers will exist in 2050, but they will have no impact on the scenarios since they will become a standard, no differentiating impact, therefore they may be involved in all possible range of the future.

In the next phase, each driving force is evaluated in a "balance test" (Mats and Hans 2009, 62) based on its certainty/uncertainty of occurrence and on the degree of its impact (the values are coming from the questionnaire). The interpretation of the two aspects in the frame of a coordinate system makes a possible structured ranking of forces for scenario-making. A further advantage is that the relationship of elements to each other from the aspect our points of view are visible and also that we may visualise the change of elements and their values in the frame of the research. Figure 1 shows the estimate of impact and uncertainties of the 124 driving forces identified in our Hungarian case study.

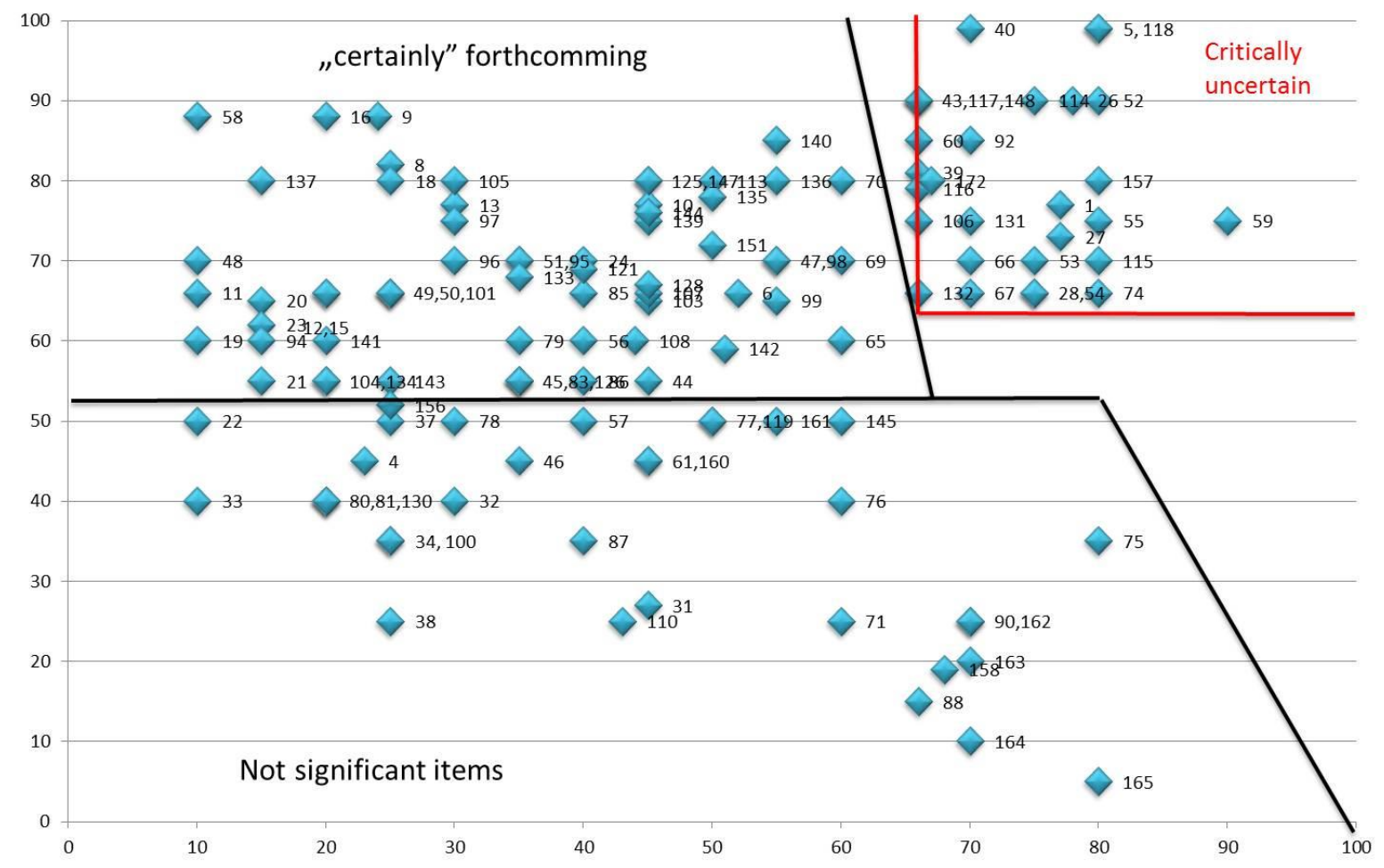

Fig 1. The estimate of impact and uncertainties of the driving forces relevant in terms of 2050. Source: Author's editing on the basis of Mats and Hans 2009, 62

Axis $X$ shows the degree of uncertainty, axis $\mathrm{Y}$ shows the magnitude of the impact exerted by the element. 
As shown in the figure, three groups of elements are distinguished:

1. Not significant items in terms of their impact,

2. Items "certainly" occurring and generating substantial impacts,

3. Critically uncertain elements, whose occurrence is uncertain, but their effects are crucial.

Separation of the sets occurs both on the $Y$ axis and on the $X$ axis at 66 , which is consistent with the Future Practice exercise, but it could even be altered (Mats and Hans do not even specify these values in their previously mentioned book).

According to the rules of future scenario-making, the critically uncertain elements are particularly important (Mats and Hans 2009, 59-62). These critically uncertain factors are considered the key factors for scenario generation.

At first, they are grouped by several criteria (listed below), then the factors constituting the scenario axes will be selected from these. Driving forces can be:

- slowly changing phenomena,

- laws of nature,

- system features,

- behaviours following from structural feedbacks in a system,

- scarce phenomena,

- ongoing phenomena,

- $\quad$ phenomena leading to inevitable conflict (Kristof, 2002, 24)

The basic criterion for selecting the scenario axes is that they should belong to the assessed factors. It is not evident, because dependent (but independent from each other) and also critically uncertain variables are needed to examine as full as possible the inner operation of the complex system. In case of selecting an independent factor, the only possibility was to examine the impact of the independent factor. But as it has already been stated, the overwhelming majority of independent variables belong to the scope of external factors; therefore, there is no internal control over them. Critically uncertain characteristics are also necessary, because they can be the special generating factors for effectively different alternatives. Selecting insignificantly influencing elements or known (certainly occurring) development factors would result in essentially the same results and only quantitatively different scenario variants could probably be developed.

\subsection{The development and re-evaluation of scenarios}

The second phase of this scenario development procedure is at first the evaluation of the identified factors and involving them into various scenarios based on the combination of their possible roles. In a second step, these generated scenarios have to be re-evaluated by experts to get consensus scenarios as the result of the procedure.

All identified key factors by scenarios get different significant values from experts, and they have to be weighted by their impact, uncertainty and occurrence. Based on a series of weighted averages, different results are obtained by factor groups and by scenarios. The procedure of calculating the weighted averages is summarised in Table 1 containing fictitious values of key factors (from the average of expert estimations), the weight of individual factors in the factor group (also estimated by experts), and the calculated value of the factor group in individual scenario types. In the research process, each component may be modified for testing and analysing the impact of different behaviours of factors. 
Tab 1. The sample table containing values, weights and weighted averages of key factors. Source: Author's calculation

\begin{tabular}{|c|c|c|c|c|c|c|c|c|c|c|}
\hline \multirow[t]{2}{*}{$\begin{array}{c}\text { Key } \\
\text { factor } \\
\text { groups }\end{array}$} & \multicolumn{4}{|c|}{ Value of the group in the scenario } & \multirow[t]{2}{*}{ Key factor } & \multirow[t]{2}{*}{$\begin{array}{l}\text { Weight of the key } \\
\text { factor in the } \\
\text { group }(1-10)\end{array}$} & \multicolumn{4}{|c|}{$\begin{array}{l}\text { Weighted } \\
\text { averages of the } \\
\text { key factor } \\
(1-10)\end{array}$} \\
\hline & 1. & 2. & 3. & 4. & & & 1. & 2. & 3. & 4. \\
\hline \multirow{4}{*}{$\underset{X X}{\text { Name }}=$} & \multirow{4}{*}{5,6} & \multirow{4}{*}{6,6} & \multirow{4}{*}{3} & \multirow{4}{*}{3,4} & Name & 3 & 1 & 2 & 3 & 4 \\
\hline & & & & & \begin{tabular}{|l|} 
Name \\
\end{tabular} & 2 & 8 & 7 & 6 & 5 \\
\hline & & & & & Name & 4 & 9 & 10 & 1 & 2 \\
\hline & & & & & Name & 1 & 6 & 5 & 4 & 3 \\
\hline
\end{tabular}

An additional opportunity comes from the table that an easily modifiable graph can be made to visualise the deviations of factors in scenarios (The Figure 3 is based on a table containing fictitious data):

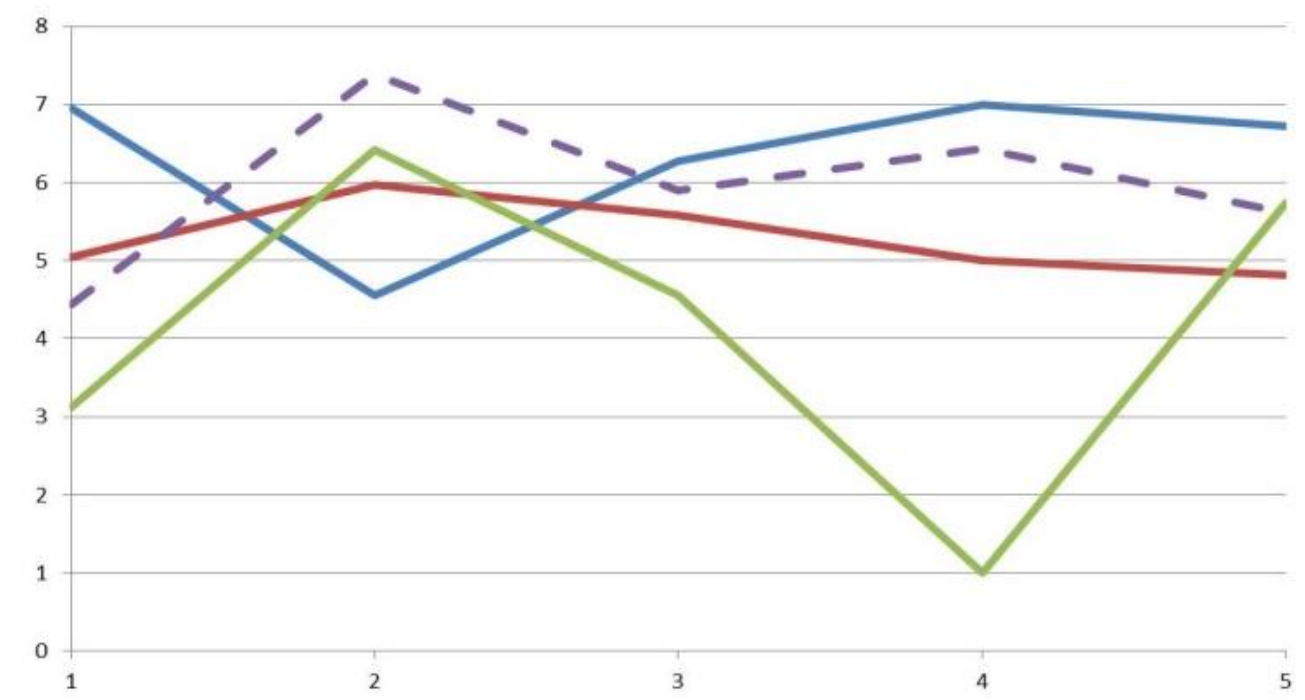

Fig 2. Sample line graph which helps to visualise the values of scenarios. Source: Author's calculation and editing

Axis $X$ presents the serial numbers of key factor-groups,

axis $Y$ presents the weighted average of the factor group in scenarios.

The continuity of the line is methodologically incorrect, but it better visualises the future-range of scenario features, their different "interfaces".

The re-evaluation procedure may include experts from relevant professional fields either in the form of questionnaire, but in our experiences the series of targeted interviews are more efficient. Two aspects are of critical importance:

- the experience and future sensibility and orientation of experts;

- concentrating the discussion on most critical aspects or points of generated scenarios, and the range of acceptable solutions.

The synthesis of the re-evaluation experiences is to obtain the range of scenarios having the greatest consensus.

\section{Hypothetical scenarios to support Hungarian absorbent rural development planning}

Based on the results of the Hungarian national analysis on the situation of rural development processes that is available in the professional literature, in national strategies and most recent studies (e.g. „European Rural Futures” project and the 2014-2020 planning project of the National Agricultural Advisory, Training and Rural Development Institute [NAKVI]), and completing with personal experiences, the authors highlighted the key factors needed for the future scenario- 
elaboration. In the SWOT, beside the elements reflecting the authors' professional opinion, only the factors originated from the sources listed above are appearing, while the elements beyond the SWOT factors needed for the STEEP analysis, the political factors are taken, for example, from referred sources. In our opinion, such is a more or less a complete picture of the Hungarian situation.

Based on the situation analysis, 172 contemporary driving forces were identified. Not all driving forces were necessary since the aim of the research required only those ones operating at macrolevel and influencing scenario generation in line with the theory of planning. Considering a large number of factors, for example, owing to opening towards regional factors, would make the model unmanageable, so it is advisable to disregard them.

The exploration of driving forces was based on the following stages:

- From the driving forces identified during the STEEP and SWOT analyses, these are sorted, which also may be driving forces in the point of view of 2050.

- The drivers for the future are examined in terms of the impact and the uncertainty.

From the 172 contemporary driving forces, which are relevant at the national level, not all would a driving force be in 2050. Based on these criteria, 48 driving strengths were not relevant for some reasons in terms of 2050 (124 is remaining). Each one of these driving forces was put on a "balance test" based on their certainty/uncertainty of occurrence and on the degree of their impact. This is presented on Figure 1 above.

A further selection and evaluation was made on the basis of earlier mentioned methodological criteria to select scenario axes. From the critically uncertain range, the diffusion of innovation and the long-term poverty were determined to key factors for scenario axes of the possible scenarios.

These two driving forces are in opposing orientation: while the diffusion of the innovation has typically a positive indication, the concept of poverty is associated with negative content. By this approach, one has the opportunity to:

- examine the mutual compensation capability of scenarios having two non-extreme values $(-+;+-)$;

- detect the tendencies due to mutual enforcing or destroying power of scenarios (synergies or antagonisms).

A further explanation of this selection is that both factors are improvable, convertible in internal, domestic competence. It is important that in contrast to other elements, they are relatively less determined, thus they show certain features of the independent variables.

At the same time, however, they essentially influence most of the key factors; they have significant impact on their operation, even if these are indirect interactions. In addition, they are soft factors, which have a decisive impact on the development of scenarios and real-life processes. They need long-term perspectives for change, they have several critically uncertain factors and the possibility of developing weak signals, therefore, they have properties to be assessed with an attitude required by futures research.

The selection of these components is further justified by the fact that most of the key factors concentrate around them (5 factors are connected with the innovation, 4 with the poverty) and both groups are listed on the basis of the previous categorisation in the scarce and conflicted groups. Consequently, they belong to the most critical factors.

Simultaneously, their advantage and disadvantage is that their trends and effects are difficult to measure, they can only be estimated with social science methods.

A further reason is to raise the innovation for a key factor that according to recent dominating economic theories, the major factor of economic growth is the knowledge-based technological development. For example, still on neoclassical economic basis, the development of technological knowledge explains nearly $80 \%$ of the GDP per capita growth (Varga 2009, 28). In addition, the innovation process is characterised by multiple and continuous feedbacks within the system. 
The first appearance of the innovation is usually in tacit knowledge that means a hidden knowledge which cannot be formally described or has not yet been described. Most of the valuable knowledge is tacit knowledge (Varga 2009, 30). Managing the spread of tacit knowledge requires different tools from that of the described, codified knowledge while its measurement requires social science measurement techniques. For the operation and survival of the spread, personal closeness is required (another matter is that such links make the flow of the described codified knowledge easy too). A further condition is the operation of an innovation chain that depends on the quality of communication on the network constituting the chain. Since the diffusion of innovation is not consistent and non-linear, it is an unstable process (Nováky, 2001, 404-407), and therefore, it is appropriate for a scenario axis in scenario building.

Poverty is a multiple and dynamic phenomenon, the aggregation of cumulating disadvantages. It reproduces itself and increases the disadvantages resulting from poverty, such as the risk of:

- factors called "hard variables” in sociology like erosion in education, type of settlement, income, etc.

- long-term unemployment,

- low level net earnings,

- inappropriate, insufficient social benefits,

- parent families,

- missing conditions to get a job (missing driver's license, lacking capabilities in computer and Internet usage),

- lack of relationship, lack of information,

- poor health, long-term illness (Obádovics-Bruder-Kulcsár 2012).

In the mirror of the facts above poverty is highly affecting the conditions of social, environmental and economic space ${ }^{8}$; therefore, it is suitable for a scenario axis. Unlike the innovation, it is judged negatively; therefore the increase in poverty worsens the situation of the entity.

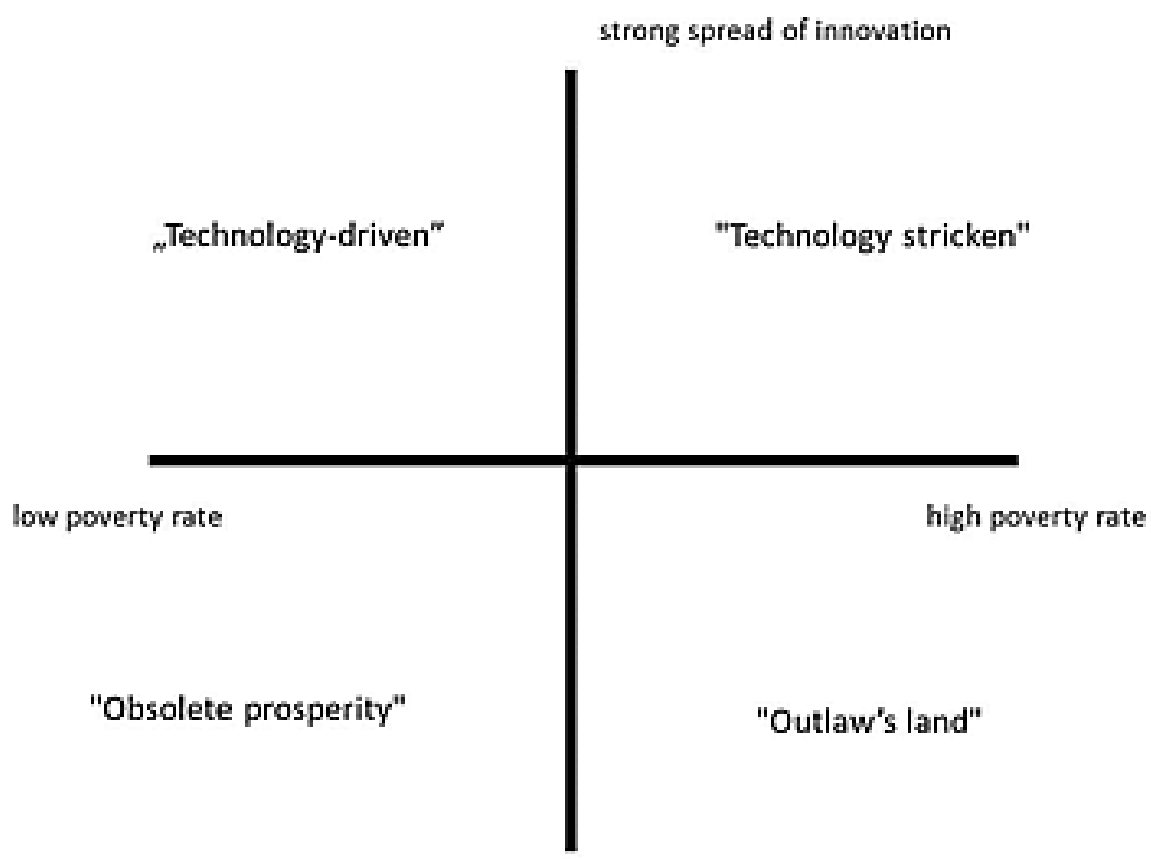

low spread of innovation

Fig 3. The four scenarios in relation to each other. Source: Author's editing

\footnotetext{
8 In spite of that, in the European rural development policy it does not have the critical mass of support. The share of promoting social inclusion, poverty reduction and economic development in rural areas is only $15.1 \%$ in the total planned public expenditure (ERND 2017, 4.).
} 
Scenarios developed along these scenario axes (Figure 3) take up the following situations characterised with terms to be discussed later:

- In the field of strong spread of innovation and low poverty rate are the "Technologydriven" scenarios (1),

- In the field of weak innovation diffusion and low poverty rate are the "Obsolete prosperity" scenarios (2),

- In the field of strong spread of innovation and high poverty rate are the "Technology stricken" scenarios (3),

- In the field of low spread of innovation and high poverty rate are the "Outlaw's land" scenarios (4).

Based on the first expert evaluation of factor values and influencing power 20 key factor groups were identified. These are:
1. social interactions
2. migrations
3. age structure
4. Romas
5. employment
6. political, administrative conditions
7. rural capacities
8. education
9. liveability, social circumstances
10. water management

11. land use

12. forestry

13. built heritage

14. settlement structure

15. economy

16. innovation

17. infrastructure

18. agriculture

19. recreation-tourism

20. energy management

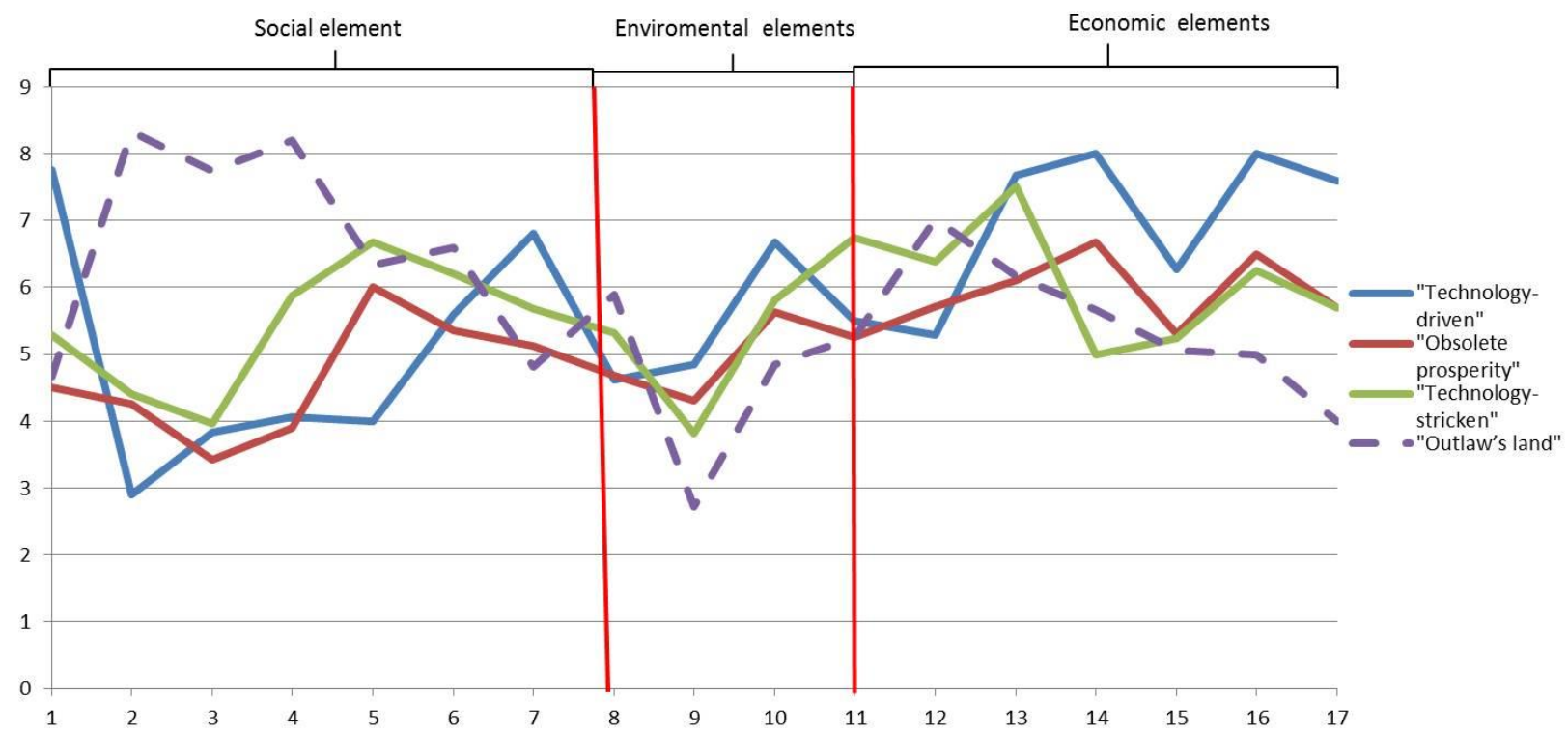

Fig 4. The modified values of the four scenarios based on the questionnaires. Source: author's editing

This zero variant was modified on the basis of a second round of questionnaires and a series of interviews. In this process, 3 factor groups (rural capacities, forestry and built heritage) proved to be omissible involving some of their factors into another factor group. This resulted in the revised line graph reflecting the changes (figure 4). It is of note that comparing to the more balanced structure of the zero variant, the role of social elements have decreased and the weight of economic elements have increased except for the "Outlaw's land" scenario.

These modified scenarios were re-evaluated again with the involvement of highly qualified experts within the framework of semi-structured interviews complying with the social sciences methodology. Focusing on the interaction of the system of various factors and the expected results, consequences of the system were discussed, thereby strengthening the foundation of 
the scenarios containing mutually acceptable future. The experts were selected from the field of rural sciences to cover the scientific rural community: technical, social, economic, agricultural, geologic, environmental, regional, international and domestic policy fields were also represented. An important selection criterion was the obligation to the scientific mainstream or to alternative guidelines. Both groups were equally represented, the former in order to include the accepted knowledge while the latter for the validation of the "thinking out of the box" logic.

There was also an age group logic in the selection of target groups: in the first stage, it was the turn of the younger generation, while in the second phase, due to the nature of the academic world, the older generation had the opportunity to give their knowledge towards the investigation. The wide age structure, from many viewpoints, strengthens the participation and the quality of collective knowledge.

In semi-structured interviews, I interviewed the most prestigious leaders of the domestic professionals about the situations, the consequences and the interactions of the scenarios. The interviews were conducted as a semi-structured questionnaire, and the subjects learned the research concept and the results of the questionnaires were sent out in the previous round. The interviews took place in the same structure.

During the nine discussions, at first the authors presented the investigation and the concept study, then the same five key questions were posed, between which informal professional discussion took place. The questions in order were targeted for: the lack of driving forces, missing critically uncertain elements, weightings the scenarios and eventually the outputs recoverable for the rural development planning.

After processing the results of the questionnaires and interviews, there was an opportunity to develop the definitive scenarios based on the appearance of new collective knowledge. The resulting four scenarios described a picture about "four Hungarian countryside" in 2050. The images outlined from the data are based on expert estimates, but stepping out from the world of indicators or figures based on their content and the additional information from experts, much colourful scenarios were generated providing lessons for rural development planning.

\subsection{The four scenarios}

1. The "Technology driven" is characterised by low level of poverty in rural areas and highly intensive innovation distribution. Technological development fulfils the conditions of weak signals. There is a technological jump of low probability but strong impact on the countryside. These changes have fast and direct influence not only on the economy but they have radical and shocking effects on social conditions (e.g. in relation to work, leisure time, etc.). It is the responsibility of rural development that before strengthening the innovation networks their impact has to be considered and the countryside has to be prepared for inclusion.

2. The "Obsolete prosperity" scenario describes a general stagnation, a kind of social moorland. Though the level of rural poverty is relatively low, this is not the result of the Hungarian rural space but it is due to the attractive external conditions. There is no dependent situation but this type of arrangement is able to react to environmental changes slowly and at low level. This future is mostly missing the adaptive capabilities and motivations. In this case, rural development has to concentrate in this case on making these factors up and revitalise them.

3. The "Outlaw's land" is the worst case scenario. Rural areas are suffering from low level of innovation and high level of poverty. The countryside is left to itself and it is also exploited. Urban areas are disposing rural resources, and the reinvestment of profits does not take place. There is no rural development. The culture of poverty goes back to traditional surviving techniques and forms of behaviour. In one possible variant of this scenario, the growing ethnic and poverty tensions resulted in a general and aggressive conflict situation, even to armed struggle. If in these circumstances there was rural development, then it would have the obligation to start a slow process initiating the development from individual level and to establish with fine field-work attracting persons and settlements in the rural space.

4. The "Technology stricken" scenario is characterised by territorially concentrated, strong innovation but high level poverty. The impact results in a strong dependent situation with 
partial profits for the countryside. There are huge differences between winning and losing areas. The industrial production and services operating on high technological level and dominated by multinational companies are located in winning areas. In losing areas, only some large agricultural organisations operate high level technologies. The missing territorial cohesion is accompanied with different chances of living. There are significant differences between technological centres and peripheries. Because the spontaneous innovation process generates concentration, in case of missing development management, the answer of rural development to this scenario may be more similar to the practice and aims of rural development in our days: i.e. regional and human equalisation.

\section{Conclusions}

1. For long-term, concept-driven planning for rural development planning, as well the assessment of the future is a necessary condition. Futures research has a pre-eminent role in the identification of concepts, and "directions" when it confronts the planner with the contradictions or coincidences between the desired and possible future. Scenarios starting from specified key factors promote the absorbent development planning to combine the achievements of planning theory and futures research.

2. According to the final scenarios, the following new and novel observations were made:

- Interesting methodological experience is that the differences between scenarios based on personal expert estimates had been reduced by the data from the survey; the differences between the curves are smoothed out while the interviews removed them from each other again, qualitatively different alternatives were re-created;

- There are components where scenarios take values close to each other. They may mean situations are different in quality but it is essential to emphasise on them as general development factors (such as educational factors). The smallest deviations are indicated at social factors, the weakest signal was in this area. One can exit the least from critical instability, and the "logic box" in this area. It can be concluded that in the possible ranges described by the scenarios, social factors are the most determined, which means that the expectations concerning the elements of this group of slowly changing factors are the most pessimistic;

- The biggest differences are the environmental and economic factors. This may reflect that those surveyed do not believe in drastic differences of slow social changes, but they can imagine completely different situations in the area of economy and nature. It is important to notice that the alienation of lines depicting the scenarios begins characteristically at the environmental forces, and the incoherence culminates at economic subjects, where totally different alternatives are observed;

- Interesting experience is that the scenarios of "Obsolete prosperity" and "Technology stricken" do not diverge from each-other (except for factors describing the settlement network); consequently, they are inappropriate to compensate each-other along the scenario axes of innovation and poverty. Though the scale and direction of parameters are different, the scenarios generated by the collective knowledge are similar;

- The "Technology-driven" scenario became a progressive variant, while the "Outlaw's land" has not become extremely negative. This is on the one hand an encouraging sign (the respondents' positive way of thinking and the avoidance of the worst possible). On the other hand, the expectation of future researchers is not achieved that an "emergency scenario" should also be prepared for the planning;

- The "Technology-stricken" and the "Outlaw's land" scenarios are characterised by the exposure to external conditions. The national rural areas have strong relations, rather dependent on external factors, despite the fact that from the scenarios, the external factors were deliberately left out. The fact that such a condition "filters through" indicates that working with external driving forces, the dependency would be even greater, and as a result, their study is a significant task for rural development. 
3. Our assumptions formulated in the hypotheses at the beginning proved to be justified only partially. The H2.1. and 2.2. hypotheses seem to be proved, since each of the four scenarios show that with a weakening agricultural function, the changes described in the hypotheses take place. The H2.3. assumption can be considered as fully proven, since each scenario strengthens the involved elements, the risk of poverty is increasing, the uncertain, volatile environment makes the planning possibilities uncertain and an appropriate innovative development offers greater potential for the rural areas. From the H2.4. statement, "with the greater satisfaction of urban social interests, the urban-rural relationship transforms" - this is considered to be proved, but it is not clear that this change is a result of changes in urban interests concerning rural areas. It is a depressing result that from the four scenarios, only one suggests (called as "Technology-driven") that H2.5. "With the greater accomplishment of the new profile of the rural area, based on social, environmental and innovation factors, the differences in the quality of life between the countryside and the urban areas would be reduced". Based on other scenarios, the differences do not decrease, but in fact they increase.

\subsection{The Discussion}

1. From the developed scenarios and the described evaluation, the conclusion is that the theoretically deemed necessity of concept-driven planning should be based on processing a very complex set of options. Significantly different scenarios may lead to substantially different visions and concepts. On this basis, and concerning the unforeseeable changes, the concept-driven planning, particularly in the phase of concept elaboration and in the resulting planning period, should constantly be flexible and open-minded concerning the factors which may change constantly and cause real differences. For developing flexibility and openness, the recipient and conformist capacity of the planning model has to be developed, therefore it should be made absorbent. The sensitive (also unstable) and large complex systems presented by the scenarios also imply that the long-term plan, the strategy should not reflect a static condition, but a dynamically changing system. All these confirm that the planning should not be an intermittent activity, but a continuous and learning process.

2. The absorbent character of planning means that it includes or "absorbs" the appearing factors (e.g. local conditions) while in the meantime, it remains open to integrate new, later emerging elements. The absorbent rural development system is the synthesis of the concept-driven rural development and the participatory futures research. The components of development can be integrated into the macro-level planning on the basis of these two disciplines. It is a confident attribute that the more emphatic is the inclusiveness is, the more absorbing capability is displayed. This is understood to the inputs coming from above or from below (the two directions are not classified, the optimum direction of problem solving determines the preference between the two), to relevant factors coming from the participatory planning process made with the involvement of non-professional people and experts as well. In a system open in this way, the concept-driven, future-oriented planning can be realised.

Specified otherwise, the planning that amalgamates the absorbent rural development and futures research involves from

- the participatory futures research

○ the long-term approach to perspectives,

- the collective knowledge, the expectations of the stakeholders, the public and non-professional aspects, and by this the democratisation,

- expert forecasts and expectations,

○ the critically uncertain factors,

- scenario-development as a method

- concept-driven strategy development

○ the common goal formation, 
o the planning through learning process,

- development plan hierarchy

o defining the components of national development in a structured and sustainable way

- social factors as network, social, health and educational components;

- ecological factors like geographical conditions, environmental desirabilities;

- economic factors like competitiveness, security of supply, selfsufficiency, financing (even projected by market research);

- scientific-technical factors like infrastructure of innovations.

The aim of absorbent rural development is to provide new elements for the macroplanning, which have qualitatively different future alternatives to conceptualising the plan. The definition of the absorbent rural development planning can be summarised in the following form:

The absorbent rural development planning is a system of planning criteria, in which the openness based on a comprehensive future understanding dominates and involving the unfolded - sometimes unlikely - rural development components and it establishes the concept orientating the long-term planning.

This interpretation of the effective long-term rural development planning is illustrated on Figure 5.

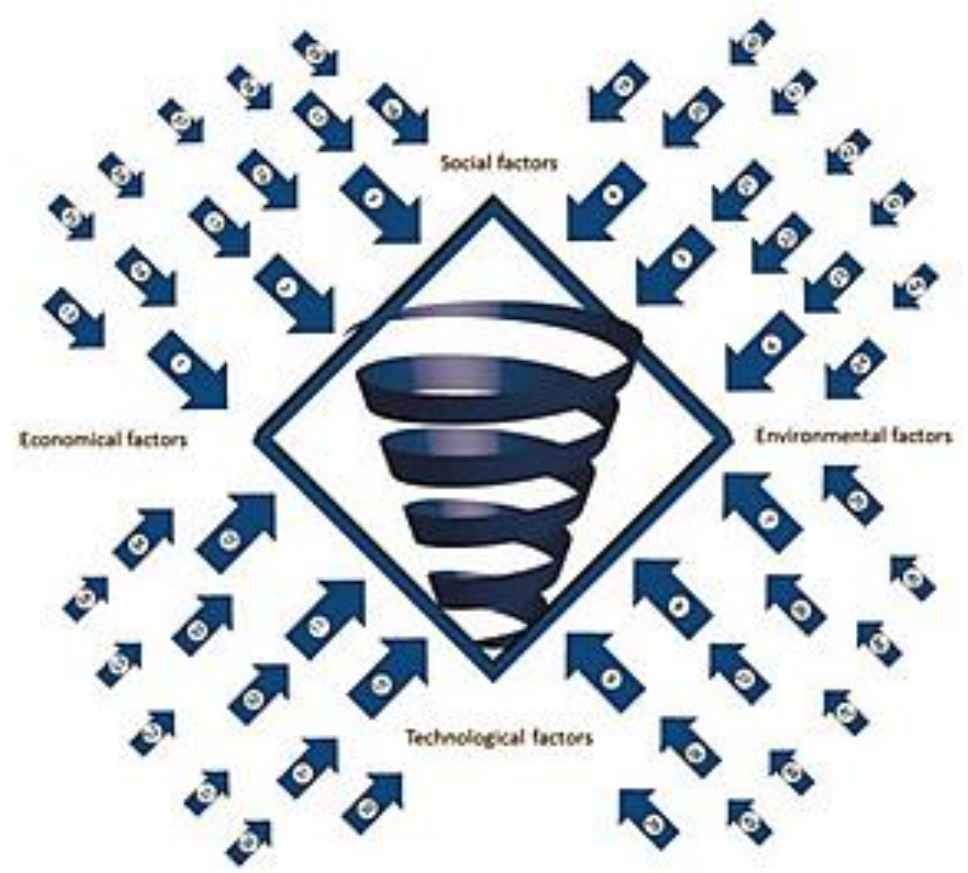

Fig 5. The swirl diagram of the absorbent rural development. Source: author's editing

The continuous whirling of factor identification and evaluation resulting in a learning process in the spiral that represent the funnel-shaped planning activity characterised by a suction effect and attracting factors of various effects and importance from different sectors.

3. Joining futures research and concept-driven planning results in more grounded long term concepts for rural development, than those without this (proving the $\mathrm{H} 1$ hypothesis). More provident planning is promoted by analysing the emerging factors of low-probability with 
strong impact. Scenario generation increases the opportunity to involve various factors and study their impact before planning decisions. Complexity needs and makes it possible through utilising this opportunity of the development of complex and different scenarios $(\mathrm{H} 1.1$. and H1.3. Hypotheses), that extend the comprehensiveness and horizon of planning (H1.4. Hypothesis). Based on the futures research methodology used in this paper, the authors think, that working with high number of driving forces, key factors and weak signals and building on their interactions, complex scenarios indicating real alternatives could be worked out, thereby providing a more complex foundation for rural development. The methodological experimentation and emphasising the contingent factors also contributed to the clarification of retroactive and multi-directional interactions in the analysis of hot spots (H1.2. Hypothesis). In this way each elements of the hypothesis group $\mathrm{H} 1$ are verified.

4. Based on these experiences, the authors are deemed proven that scenario-making as a planning tool, as well as the long-term (even extended up to 2050) approach are necessary and appropriate for national rural development planning, but they may also serve as a model for local planning. They offer strong foundation to the synthesis of the participatory futures research and the concept-driven planning to promote rural development.

\section{Academic references}

[1] Allmendinger, P. \& Haughton, G. (2010). Spatial planning, devolution, and new planning spaces. Environment and Planning C: Government and Policy 28(5), 803-818. DOI: $10.1068 / \mathrm{c} 09163$.

[2] Asher, W. \& Overholt, W. H. (1983). Strategic Planning and Forecasting. Political Risk and Economic Opportunity, New York: John Wiley \& Sons.

[3] Cloke, P. J. \& Park, C. C. (1985). Rural resource management. New York: St. Martin's Press.

[4] Enyedi, Gy. (2010). Terület- és településfejlesztéssel kapcsolatos tudományos kutatások fö irányai és feladatai. Területi Statisztika 4, 398-405.

[5] Faragó, L. (2003). Koncepcióvezérelt tervezés általános elmélete [PhD. Theses]. University of Pécs.

[6] Faragó, L. (2005). A jövőalkotás társadalomtechnikája. Budapest-Pécs: Dialóg Campus Kiadó.

[7] Fehér, A. (1998). A vidék fogalmáról és a vidéki területek lehatárolásáról. Gazdálkodás. 42(5), 54-59.

[8] Ferge, Zs. (2007). Mi történik a szegénységgel? Csalóka „posztmodernitás”. Esély 18(4), 323.

[9] Gábor, É., ed. (1976). A kívánt jövőtől a lehetséges jövőig. Budapest: Gondolat.Kiadó.

[10] Glatz, F. (2008). Új vidékpolitika. Budapest: MTA Társadalom Kutató Központ.

[11] Korompai, A. (1995). Regionális stratégiák jövőkutatási megalapozása. Regionális Tudományi Tanulmányok 1.

[12] Korompai, A. (2006). Kérdések a területfejlesztési dokumentumok jövőképeinek változásai kapcsán. In Kristóf, T. \& Tóth, A., eds. Globális és hazai problémák tegnaptól holnapig (pp. 216-219). Budapest: Magyarság Kutató Intézet.

[13] Kovách, I. (2012). A vidék az ezredfordulón. A jelenkori magyar vidéki társadalom szerkezeti és hatalmi változásai. Budapest: Argumentum Kiadó.

[14] Kristóf, T. (2002). A szcenárió módszer a jövőkutatásban [technical report]. Budapest: Corvinus University. DOI: 10.13140/RG.2.1.4277.4481.

[15] Makkai G. (2008). Vidékfejlesztés. Marosvásárhely: Mentor Kiadó. 
[16] Mats, L. \& Hans, B. (2009). Scenario Planing. The links between future and strategy. Basingstoke: Palgrave and Macmillan.

[17] Meadows, D. H., Meadows, D. L., Randers, J. \& Behrens, W. W. (1972). Limits to growth. New York: Universe Books.

[18] Mészáros, B. (2012). A vidékies térségek jövője Közép-Európában. Falu, város, régió 2012/1-2. 46-54.

[19] Nováky, E. (2001). A tudományos-technológiai előrejelzéstől a technológiai előrelátásig. In: Nováky, E. Jövőkutatási tanulmányok 1998-2005 (pp. 404-413). Budapest: Corvinus University.

[20] Nováky, E., ed. (2006). Jövőkutatás. Budapest: Corvinus University.

[21] Nováky, E., ed. (2008). Változás és Jövő. Budapest: Püski.

[22] Obádovics, Cs., Bruder, E. \& Kulcsár, L. (2011). A gazdasági és szociális helyzet területi egyenlőtlenségei a vidéki Magyarországon - hasonlóságok és eltérések. In Bódi, $F$. \& Fábián, G., eds. Helyi Szociális ellátórendszer Magyarországon (pp. 141-155). Debrecen University Press.

[23] Randers, J. (2012). 2052: A Global Forecast for the Next Forty Years. White River Junction: Chelsea Green Publishing.

[24] Roney, C. W. (2010). Intersections of Strategic Planning and Futures Studies: Methodological Complementarities. Journal of Futures Studies 15(2), 71-100.

[25] Schoemaker, P. J. H. (1995). Scenario Planning: A Tool for Strategic Thinking. Sloan Management Review 36(2), 25-40.

[26] Schwartz, P (1996). The Art of the Long View: Planning for the Future in an Uncertain World. Currency New York. Doubleday.

[27] Szabó, M. (2015). Az abszorbens országos vidékfejlesztési tervezés megalapozása forgatókönyvekkel [PhD thesis]. Budapest: Eötvös Loránd University.

[28] Varga, A. (2009). Térszerkezet és gazdasági növekedés. Budapest: Akadémia Kiadó.

[29] Veigl, H. (2009). Interpreting and using weak signs in futures studies. Hideg, É., ed. Futures Studies in the Interactive Society (pp. 129-142). Budapest: Corvinus University.

\section{Other sources}

[30] ERND (2017): RDPs 2014-2020. Key facts \& figures. Rural Development Priority 6: Promote social inclusion, poverty reduction and economic development in rural areas. Retrieved from https://enrd.ec.europa.eu/sites/enrd/files/priority-6-summary.pdf (accessed: 03.07.2017).

[31] Nemzeti Fenntartható Fejlődési Tanács (2010). Jövőkereső. A Nemzeti Fenntartható Fejlődési Tanács jelentése a magyar társadalomnak. http://www.nfft.hu/dynamic/Jovokereso_Hosszu_Screen.pdf (downloaded: 24.01.2013).

[32] Nemzeti Vidékstratégiai Koncepció - 2020 II. (agrár-, élelmiszer-, környezet- és vidékstratégiai alapvetések) VM, Budapest, 2011.

[33] Organisation for Economic Co-operation and Develpoment (1999). Energy: The Next Fifty Years. Retrieved: http://www.oecd.org/sti/futures/17738498.pdf (accessed: 3-10.01.2013).

[34] Pietersen, W. G. (2004). Strategic Learning. A Leadership Process for Creating and Implementing Breakthrough Strategies. http://williepietersen.com/wpcontent/uploads/pdf/Strategic_Learning.pdf letöltés ideje: 2015 November 20.

[35] The Millennium Project: Global Normative Scenario - 2050. Retrieved http://www.millennium-project.org/millennium/normscen.html (accessed 3-10.01.2013). 
[36] Új Magyarország Vidékfejlesztési Program, 2008.

[37] World Business Council for Sustainable Development Global Scenarios 2000-2050 (1997). Exploring http://www.wbcsd.org/pages/edocument/edocumentdetails.aspx?id=143 (accessed: 310.01.2013). 